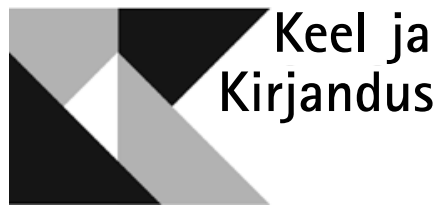

$6 / 2016$

LIX AASTAKÄIK

EESTI TEADUSTE AKADEEMIA JA EESTI KIRJANIKE LIIDU AJAKIRI

\title{
PALJAS ELU LAAGRIMÄLESTUSTES JA JAAN OKSA PROOSALOOMINGUS
}

\author{
LEO LUKS
}

J aan Oksa loomingut ümbritseb tänini teatav saladuseloor. Ühelt poolt märgati selle loomingu erakordsust ja kujundirikkust juba Noor-Eesti õitseajal, ennekõike Tuglase poolt. Teisalt on Oksa tõlgendamine jäänud tänini põgusaks ja visandlikuks; ka artikli mõõtu tõsisemaid uurimusi võib ühe käe sõrmedel üles lugeda (Palgi 2003; Grünthal 2001; Süvalep 1996; Heero 2005; Lukas 2005). Ebalusest Oksa käsitlemisel võib aru saada: erinevalt paljudest kaasaegsetest (kas või Juhan Liivist) ei sobitu Oksa ilukirjanduslik looming ei kriitilise realismi ega ka rahvusliku äratuse kategooriasse, olles juba seetõttu mõistetud eesti kirjandusuurimise peavoolust kõrvale jääma. Kuid probleem on sügavam: Oksa tähelepanuväärsematest proosapaladest pole sugugi lihtne välja lugeda, mis seal juhtub, rääkimata sellest, miks nõnda juhtub. Sestap on Oksa loomingu iseloomustamisel õigustatult kasutatud mitmeid kirjandusteoreetilisi silte, nagu ekspressionism (Heero 2005), sümbolism, modernism (Süvalep 1996), dekadents jne. Kuigi olen ka ise varem üritanud Oksa loomingut paari märksõna varal tõlgendada (Luks 2015), ei tundnud ma seejuures sugugi, et oleksin loetut piisaval määral mõistnud.

Ehk tulekski loobuda katsetest tõlgendada Oksa loomingut ideelise tervikuna, piirdudes sümbolite tulevärgi nautimisega? Ainest selliseks käiguks võime leida ka ühest Oksa erakirjast: „Oma „sisu” puudusest saan ise ka väga hästi aru. Kuid see on meelega nii. [---] Filosoofiline elu on niisama tühi, kui meie teda hallutsinatsioonidega ei sisusta. Mälu ei ole kunst, ja kopeerimine ei 
ole kunst. Keeleilu on kõik, kuna igatõuliste sündmuste vaheldumise kirjeldus ennegi haigeid inimesesoo närvisi vaevab." (Oks 2004: 266)

Ometi iseloomustab Oksa loomingut lisaks eelpoolmainitule veel ka temaatiline maalähedus, külaelunaturalism - ehk vaid seksuaalsete tungide sügavusse kaevuvad kirjatööd („Emased”, „Ihu”, „Nimetu elajas”) jäävad sellest määratlusest väljapoole. Piisab, kui võrrelda hetkeks Oksa proosapalu Tuglase sümbolistlike novellidega, et mõista: Oksa loomingus ei ole tegu pelgalt hallutsinatsioonide virvarriga, siin on mängus mingi järjekindel, tervet elu varjutav raskuse vaim. Aga mis nimelt?

Käesolevas artiklis üritan kaitsta hüpoteesi, mille kohaselt visandatakse Oksa loomingus järjekindlalt palja elu kontuuri. Palja elu mõiste, mida ma oma käsituse tarbeks laenan, on pärit Giorgio Agambeni poliitilisest filosoofiast ning iseloomustab igasugusest mõttest tühjenenud inimelu, pelka elusolemise fakti. Ka eesti keeles loetavas teoses „Homo sacer” esitab Agamben palja elu seisundi iseloomustamiseks mitmeid näiteid (Agamben 2009: 194-202); siinses artiklis võtan Oksa loomingu tõlgendamise juhtlõngaks neist ainult ühe, mis pakub kõige selgemat ja viljakamat võrdlusalust ning on Agambeni jaoks tähtsaimal kohal modernsuse poliitilise loogika mõistmisel. Selleks näiteks on paljaks eluks taandatud koonduslaagri elanik (Agamben 2009: 183), kes kuhtub oma seisundi äärmusse jõudes tahtetuks ja peaaegu teadvusetuks „elavaks surnuks”. Teema käsitlemisel ei piirdu ma Agambeni filosoofilise prismaga, vaid võrdlen Oksa loomingut jõudumööda mitmete dokumentalistliku taustaga teostega, kus kirjeldatakse elu natside koonduslaagris ning stalinistlikus vangilaagris. ${ }^{1}$ Antud võrdlusest kasvavate üldistuste ja järelduste abil üritan näidata, et Oks pole sugugi üksnes servapidi ja stilistiliselt modernismiga, ekspressionismiga ega dekadentsiga seotud autor, vaid tema kohta kehtib ka praegu Ivar Grünthali 1956. aastal antud hinnang: „Eesti kirjanduse esimese moodsa inimesena nägi ta üle oma aja. Ta loomingu magmas tuksleb tükeldatud tänapäev" (Grünthal 2001: 24-25). Artikli lõpus spekuleeringi pisut selle üle, millisena paistab meie tänane elu Oksa loomingu ja koonduslaagri-jutustuste peeglis.

\section{Inimlik eluvorm ja paljas elu}

Palja elu mõiste on keskne Agambeni poliitikafilosoofia suurteoses „Homo sacer". Käsitus saab alguse tähelepanekust, et vanadel kreeklastel oli elu mõiste tähistamiseks kaks erinevat terminit: zoe väljendas pelgalt elamise fakti, mis on ühine kõigile elavatele, bios aga mõnele üksikisikule või grupile eriomast eluvormi (Agamben 2009: 9). Aristotelesest alguse saanud mõjuka lähenemisviisi kohaselt on inimesele kui keele valdajale omane eriline poliitiline eluvorm (bios politikos), mis tähendab hea, hüvelise kogukonna poole püüdlemist. Agambeni jaoks on otsustava tähtsusega, et aristotellikus käsituses välistatakse poliitilisest elust elu kui selline (zoe), sealhulgas esmaste eluprotsesside taastootmine, mis jääb suletuks kodusesse sfääri (oikos, vt

\footnotetext{
${ }^{1}$ Kuna eesti keeles loetav materjal on piiratud ja juhuslik valim, ei taotle ma antud kirjatööga siseneda akadeemilisse holokaustiuuringute diskursusesse. Mu essees kasutatav materjal ei võimalda teha lõplikke ja detailseid üldistusi laagrielu kohta, siiski on allikate arv piisav, et visandada mõned struktuursed ühisjooned.
} 
Lipping 2004: 187). Inimese pelk elu kui selline jääb ometigi just selle väljaarvamise läbi ühiskondliku korraga seotuks (Agamben 2009: 17): näiteks on suveräänil õigus kehtestada eriolukord ja otsustada alamate elu ja surma üle. Michel Foucault' biopoliitiliste analüüside jälgedes käies paneb Agamben tähele, et modernset poliitikat iseloomustab palja elu nihkumine erandi staatusest reegliks:

...koos protsessiga, mille läbi erandist saab igal pool reegel, hakkab palja elu ruum, mis algul asus ühiskondliku korra äärealadel, üha enam ühte langema poliitilise ruumiga ning väljajätmine ja kaasamine, väline ja sisemine, bios ja $z o e$, õigus ja fakt satuvad taandamatu eristamatuse tsooni. (Agamben 2009: 15)

Ühelt poolt annavad selliseks tähelepanuks alust natsism ja fašism, „mis on teinud otsustusest palja elu üle kõrgeima poliitilise kriteeriumi” (Agamben 2009: 16), kuid sama suundumus leiab aset ka moodsates vaatemänguühiskondades, massilise tarbimise ja hedonismi ühiskondades (Agamben 2009: 17). „Meie poliitika ei tunne tänapäeval muud väärtust (ja sellest tulenevalt ka muud antiväärtust) kui elu...." (Agamben 2009: 16). Agamben keskendub oma uurimuses just nendele poliitilistele välistamisprotseduuridele, kus inimelu taandatakse paljaks eluks, jäetakse ilma igasugusest juriidilis-poliitilisest subjektsusest. Tema üldised järeldused on küllaltki lohutud: algne poliitiline suhe on välistamine (sissearvava väljasulgemise mõttes); suveräänse võimu põhitegevus (st varjatud toimeloogika) on toota paljast elu; lääne biopoliitiline paradigma on tänapäeval laager, mitte linn (Agamben 2009: 194). Paljas elu, pelgalt elusolemise fakt ei ole inimesele omane ega võimalik. Õigupoolest, nagu peagi näeme, võib ka inimene mõnes äärmuslikus olukorras sedalaadi seisundisse sattuda, kuid seda pole võimalik käsitleda ühe loomuliku, inimesele kohase eluviisina teiste seas. Agambeni jaoks pole paljas elu ei zoe ega bios, see pole inimlik ega animaalne, vaid ebainimlik piirsituatsioon (De Boever 2011: 30), ,inimese ja metslooma, looduse ja kultuuri vahelise eristamatuse ning pideva üksteiseks ülemineku tsoon" (Agamben 2009: 120). Kui nüüd esitada küsimus, mis on inimesele omane eluviis, siis Agambeni vastus kõlab: selline elu, mida ei saa eraldada tema vormist.

[Inimelu] üksikud viisid, teod ja protsessid pole kunagi lihtsalt faktid, vaid alati ja eelkõige elu võimalused, alati ja ennekõike vägi [potenza]. Käitumisviise ja inimliku elamise vorme ei kirjuta kunagi ette mõni spetsiifiline bioloogiline kutsumus ega tee meile ülesandeks mõni hädatarvidus, vaid - kuivõrd need on sisseharjutatud, korduvad ja sotsiaalselt kohustuslikud - nad talletavad alati võimaluse loomujoone, see tähendab panevad mängu elamise enese. Seetõttu - kuivõrd ta on väe olend [essere di potenza], kes võib teha või mitte teha, õnnestuda või läbi kukkuda, end kaotada või leida - on inimene ainus olend, kelle elamises on küsimus alati õnnes, kelle elu on parandamatult ja valusalt onne hoolde antud. Aga see konstitueerib elu-vormi otsekohe ka kui poliitilise elu. (Agamben 2015: 83-84)

Antud tsitaadist näeme, et inimlik elu ei ole kunagi pelgalt faktiline, vaid alati seotud teatud võimaluste, soovide, unistuste realiseerimisega ja sageli ka luhtumisega. Inimene on õnne (ja õnnetuse) hoolde antud, kuna tema jaoks ei 
ole see, mis juhtub, kunagi ainumõeldav, vaid suhestub alati temas avaneva võimaluste väljaga. Tasub toonitada, et tsiteeritud lähenemises ei oponeeri Agamben mitte üksnes suveräänse võimu paljast elu tootvale vägivallale, vaid ka seda võimaldavatele eeldustele: juba see, kui hea elu, õnn võtab inimese jaoks etteantud vormi (nt tuleb olla edukas haritud inimene või rahvuslane), piirab liigselt inimesele omast väelisust. Juba aristotellikus elu ja hea elu eristuses peitub viga, kuna „õnne valem” antakse mingi valmis eluvormina (väärtuste, hüvede, vooruste kogumina) ette.

Lisan eelnevale mõttekäigule täpsustuseks ajamõõtme: nagu näitas juba Martin Heidegger (2003: 1032), „elab” inimene võimaluste olendina ennekõike tulevikus, esitab elule nõudmisi ja pürgimusi, ei neeldu hetkeaskelduste automatismi. ${ }^{2}$ Inimene on läbinisti poliitiline loom, ta ei taha pelgalt elus püsida, vaid hästi elada, ennast teostada (vt Lipping 2004). Selle lihtsa tõdemuse tunnistamine tähendab seda, et me aktsepteerime inimese või ka inimgrupi subjektsust, isegi kui pole võimalik tema nõudmisi rahuldada.

Agamben uurib poliitikafilosoofina valdavalt neid eri ajastutest pärinevaid ning modernsuses kulmineeruvaid võimumehhanisme, mis „toodavad” paljast elu, taandavad kellegi (näiteks Vana-Rooma lindprii, homo sacer'i või koonduslaagri elaniku) ilma igasuguste õigusteta seisundisse, kus võim ei avaldu enam käskude, keeldude ega karistustena, vaid töötleb otseselt kehasid. Vähem on pööratud tähelepanu n-ö palja elu fenomenoloogiale, selle seisundi hüpoteetilisele kirjeldamisele, kuigi Agamben on seda siiski oma Auschwitziteoses (1999) mõnevõrra pikemalt nn musulmani kuju abil portreteerinud. Tuleb rõhutada, et palja elu juriidiline ja fenomenoloogiline määratlus ei kattu; lindprii, ori või koonduslaagri juut on kõik juriidilis-poliitilises mõttes mitte-subjektid, välja arvatud, kuid ometigi ei taga see määratlus automaatselt, et nad oleksid kaotanud sisemise vabaduse, hea elu poole püüdlemise võime. Sedasama on oma kriitikas märganud Ernesto Laclau (2007), eritledes „Homo saceris” palja elu mõiste alla toodud erinevaid näiteid: Rooma preestrit, lindpriid, füürerit, koonduslaagri musulmani, oma kehaga katsetavat bioloogi ning komaatikut (Agamben 2009: 195-200). Laclau toob esile, et kõige puhtamalt sobib paljast elu ilmestama teatud juriidilise nõude tõttu masinate abil elus hoitav komaatik: keha, mis on täielikult eristatud isikust, kes seda elu subjektiivselt elas. Samuti nõustub Laclau nimetama paljaks eluks musulmani elu, millest tuleb ka siin artiklis peagi juttu (vt Laclau 2007: 18-19). Kuid Agambeni uurimusele pealkirja andnud lindprii (homo sacer'i) elu ei vasta sugugi palja elu kõikidele tunnustele: lindprii on üksnes juriidilises tähenduses poliitilisest kogukonnast välja arvatud (millega kaasneb mõistagi tegelik oht elule, kuna igaüks võib teda karistamatult tappa). Samas on ta täiesti võimeline osalema antagonistlikes sotsiaalsetes praktikates ning isegi kujundama oma võimaluste piires õnneliku elu, õige elu kujutelma (nt nn vargaeetika või õilis-õiglane Robin Hood). Lindprii puhul ei toimu konflikt seaduse ja pelgalt elava keha vahel, vaid erinevate seaduste vahel (Laclau 2007: 19).

\footnotetext{
${ }^{2}$ Siiski juhtub inimese elus ka seda: neeldumine igapäevaelu käepärasusse (Zuhandenheit), igamehe (Man) kombel lobisemine (Gerede) (vt Heidegger 1967, § 15, 27, 35), kriitikavaba askeldamine moodsat ühiskonda korraldavas tehnika seade-stus (Ge-stell, Heidegger 1989) on Heideggeri jaoks inimese kohutavaim võimalik saatus, mille vastu on suunatud kogu tema autentsuse retoorika vägi. Agambeni terminites öeldes kogeb Heidegger ehedalt palja elu kasvavat ähvardust.
} 
Kui enamasti kulub mõtlejate (sh Foucault' ja Agambeni) põhiaur välistamisprotsesside ebaõigluse paljastamisele, siis järgnevas analüüsis keskendun just palja elu seisundi fenomenoloogilisele vaatlusele. Selle all pean silmas olukorda, kus inimelu tühjeneb talle omasest tähenduslikkusest, õnneihalusest, kaldub olema veel pelgalt fakt. Plaanitava rõhuasetuse mängib mulle kõige ehedamalt kätte Jaan Oksa proosalooming ise, kus igasuguste sotsiaalsete konfliktide kujutamine samahästi kui puudub; imelik-ängistav külaelu avaneb isoleeritud immanentsuses. Seevastu siinse artikli teises uurimisobjektis, laagrimälestustes, avalduvad selgelt ka paljast elu „tootvad” välistusprotseduurid. Kuna paljas elu ilmneb õudse fenomenina alati kellelegi, mõnele inimliku eluvormi kandjale, siis tuleb täpsustuseks mainida, et järgnev essee ei piirdu palja elu isoleeritud vaatlusega, vaid haarab nii Oksa proosaloomingu kui ka laagrimälestuste puhul kaasa ka vahetu vaatleja perspektiivi.

\section{Elavad surnud: „musulman” ja talupoeg}

Eelmises alajaotuses välja töötatud eristusest lähtudes alustagem põhilisest: Oksa tegelased on valdavalt väetud olendid, kes ei ole suunatud tulevikuvõimaluste poole. Nad on apaatsed „zombid”, kes kulgevad külaelu troostitus miljöös, mis sekundeerib orgaaniliselt nende vaimuseisunditele. Seda üldist hinnangut süvendavad mitmed varem märgatud detailid: tegelastel pole tundeid, nad on esemetega samastumas, sageli ei kasutata nende kirjeldamiseks pärisnime (Heero 2005: 203), nende isiksus ei joonistu välja, vaid avaneb üksnes visandina monotoonses tegevuses.

On oluline rõhutada, et Oksa juttudes pole säärane tardunud eksistents traagiline, kellegi (nt mõisa) pahatahtlikkuse süü. Erinevuse hoomamiseks võiks põgusalt võrrelda mõnd Oksa juttu (nt „Küla” või „Vaevademaa”) Juhan Liivi „Varjuga”. „Varju” alguses kirjeldatakse Kukulinna Oksale küllaltki sarnases troostitus võtmes (Liiv 1956: 100-101); jutu lõpus leiame peategelase vaimsest hämarolekust, mida võiks tulevikku suunatud onnneihaluse puudumise tõttu samuti paljaks eluks nimetada (Liiv 1956: 165). Kuid vahepeale jääb klassikaline inimlikule eluvormile omane traagika: parema elu taotlus, võitluslik pinge vaenlasega (hädavajalik iga poliitilise asetuse jaoks), mis päädib tulevikutaotluste luhtumise ning vaenlasele allajäämisega.

Järgneva analüüsi tiibu kärpides tuleb tõdeda, et mitte kõigis Oksa novellides pole elu monotoonsus viidud sellisesse äärmusse, et seda sobiks paljaks eluks nimetada. Kuigi heroilisi taotlusi ei leidu kusagil - suurimaks konfliktiks on töömeeste lahkumine kehva teenistuse paigast („Viimane töötund”) -, on terve rida Oksa laaste pelgalt argielupildikesed (nt „Kolmekesi”, „Heinamaal”, „Aprillihommiku vihm”, „Leivategemise kord”) või siis ülevaated mõnest pisut erilisemast sündmusest („Naisevõtmine”, „Manifesti ajal”, „Viimane koosolek”, „Koolmeistri hobune”). Oma analüüsis toetun novellidele, kus on miljöö ja tegelaste viletsust võimendatud nii kirjelduste kui ka säärasele eksistentsile antavate hävitavate kõrvaltvaate-hinnangute kaudu (nt „Vaevademaa”, „Küla”, „Neljapäev”, „Perekonna hommikutund”, „Suu”). Vürtsi lisavad säärased jutud, mis kuulutavad elu kui terviku luhtunuks ning manifesteerivad vabasurma („Vana madrus”, „Hauakõne”, „Tume inimeselaps”, „Udukogus”). 
Aigi Heero (2005: 201) paneb õigesti tähele: „Paljudes Oksa tekstides justkui kaob piir elusa ja elutu vahel, mis manab silme ette pildi deemonlikust, õovastavast maailmast...." Ometi ei ole see maailm üles ehitatud õuduskirjanduse reeglite kohaselt, nagu kas või Ansomardi või Juhan Jaigi juttudes. Oksa juttudes ei võta kuju ükski võõras vaenulik olend, kõik on küll ebaõdus (Unheimlich), aga samas ka argine ja igav. Oksa maailma tegelased on küll n-ö zombid, aga mitte õudusfilmidest tuttavad a g res s i iv s ed zombid. Oks ei konstrueeri ekstreemsituatsioone - kuigi tema külaelanikud nimetamisi küll alatasa nälgivad (Oks 2003: 126, 163; kogu „Otsija metsas” siin edaspidi OM), ei kirjeldata kusagil detailselt näljahäda, taudi vms.

Heidame nüüd pilgu koonduslaagrisse. Esmapilgul tundub, et laagrielaniku sarnasused Oksa talupoegadega on napid ja ebaolemuslikud: alatoitumus, nüri ja lõputa töö, mis muudab inimese tuimaks. Erinevused paistavad hoopis olulisemad: koonduslaagrite elanikud on vangid, keda ähvardab igal hetkel surm gaasikambris või „laagriautoriteetide” käe läbi; nende olukord on tajutavalt erakordne ning ebaõiglane - Oksa külaelu kohta ei saa vähemalt sündmustiku tasandil midagi sellist väita.

Võrdlusaluse selgitamiseks tuleb elu koonduslaagris pisut täpsustada. Kõik mulle teadaolevad laagrimemuaarid kinnitavad üldistust, et sealne elu oli lakkamatu „ellujäämiskursus”. Tavalises töökomandos töötav ja vangile ette nähtud portsust toituv inimene suri Primo Levi väitel enamasti nälja ja kurnatuse kätte kolme kuu jooksul:

Alles jäid ainult arstid, puusepad, kingsepad, muusikud, kokad, noored atraktiivsed homoseksuaalid, mõne laagriautoriteedi sõbrad või kaasmaalased; lisaks kõige halastamatumad, tugevamad ja ebainimlikumad indiviidid, kellest said kapod, Blockältester'id või muud asjamehed.... ja lõpuks need, kes polnud küll valitud kindlasse ametisse, kuid suutsid tänu kavalusele ja tarmukusele olla alati head organisaatorid.... (Levi 2004: 77) ${ }^{3}$

Laagri-raamatute minategelased kuuluvadki üldiselt sellesse loetellu, enamasti spetsialistidena; kuigi mõned maitsevad vahepeal ka lihtvangi leiba ning satuvad hukkumise äärele (Sruoga 1976: 98-101). Kurnatud vangi teadvuses võistlevad omavahel pidevalt elu eest võitlemise tung ning üldise apaatiana avalduv tahtmine alla anda. Lisaks pidevale kombineerimisele ja laveerimisele tähendas võitluse jätkamine ka tahtejõu säilitamist, seda hoidvate enesetehnikate praktiseerimist - näiteks enda vabatahtlikku pesemist ja raseerimist kurnatusele vaatamata. „Need reeglid olid ühenduslülid, mis sidusid mind mu inimliku eksistentsiga" (Frister 2005: 297). Psühholoog Viktor E. Frankli jaoks (2002: 17) oli oluliseks enesetehnikaks laagrielu, sh iseenda olukorra analüüsimine teadlase pilgu läbi. Ta oli veendunud, et inimese kestmine või kuhtumine ning samuti inimliku moraalse pale säilitamine või kaotamine ei ole välistingimuste poolt determineeritud, vaid vaba valiku tagajärg. Frankl pidas otsustavaimaks tahet säilitavaks elemendiks tulevikueesmärgi olemasolu vangi teadvuses (vt Frankl 2002: 100-110), ükskõik kui ebatõenäoline selle täitumine ka poleks:

\footnotetext{
${ }^{3}$ Lisaks viidatud raamatule kirjeldab koonduslaagris valitsevat hierarhiat ning eluspüsimiseks vajalikke „organiseerimise” nippe kõige detailsemalt Sruoga 1976.
} 
Kes enam ei suuda uskuda tulevikku, oma tulevikku, on kadunud hing. Koos tulevikuga kaotab ta vaimse pideme, laseb end käest ja variseb kokku nii kehaliselt kui ka hingeliselt. [---] Tavaliselt nägi kriis välja nii, et sõber jäi ühel päeval barakki lebama ja ükski jõud ei suutnud teda sundida end riidesse panema, pesuruumi minema ja kogunemisväljakule tulema. [---] Ta oli alla andnud! Ta jäi lebama isegi omaenda väljaheidetesse. Ta ei hoolinud enam millestki. (Frankl 2002: 102-103)

Agambeni teoreetilist eristust meenutades säilitab laagrielanik vaatamata kurnatusele, praktiliste tegutsemisvõimaluste ahtusele ning teda ähvardavale surmale senikaua inimliku eluvormi, kuniks temas elab parema tuleviku lootus. Eelmises tsitaadis kirjeldati just üleminekut inimlikust eluvormist paljasse ellu.

Ometi ei tähendanud allaandmine alati lõplikult lebama jäämist. Enamasti muutus allajääja zombilikuks elavaks surnuks, keda hüüti laagriargoos „musulmaniks”. ${ }^{4}$ Esitan nende kohta mõned iseloomulikud kirjeldused:

Nende elu on lühike, kuid neid on otsatult palju, just nemad, musulmanid, allajääjad, toidavad laagrit; nemad, anonüümne mass, ikka uuenev ja ikka seesama, mitteinimesed, kes marsivad ja rügavad vaikuses, neis on kustunud jumalik säde ja nad on juba liiga tühjad, et tõeliselt kannatada. Raske on nimetada neid elavateks; raske on nimetada surmaks nende surma, mida nad ei karda, sest on liiga väsinud, et seda mõista.

Need inimesed täidavad mu mälestused oma näota ligiolekuga, ja kui püüaksin mahutada ühte kujundisse kogu meie aja kurjuse, siis valiksin just selle, mida ma tunnen: kuhtunud mees, otsmik ja õlad längus, kelle näost ega silmist pole võimalik välja lugeda ühtegi mõtet. (Levi 2004: 77)

Kas te juba teate, keda meil musulmaniks kutsutakse? Haletsusväärset kuju, kes on omadega läbi, näeb välja haige ja nälginud ega saa enam teha rasket kehalist tööd. (Frankl 2002: 33-34)

Teatud kauguselt vaadates on kõik ainult muldvanad ätid, kes oma õlgade vahele tõmmatud pea, terava nina ja kondistel õlgadel lotendava räpase vangihõlstiga meenutavad ka kõige kuumemal suvepäeval igavesti külmetavaid talviseid vareseid. (Kertész 2004: 87)

Agamben nimetab musulmani läveks, kus inimene muutub mitte-inimeseks (1999: 47). Musulmanid olid välja arvatud ka vangide omavahelisest hierarhiast ja suhetest, mõjudes hirmutava hoiatusena: „Kui nendele otsa vaadata, läheb eluisu ära” (Kertész 2004: 88). Teisi vange võis huvitada vaid mõni parem riideräbal, millele musulmani peatse surmaga arvestades pilk peale visati (Frankl 2002: 76).

\footnotetext{
${ }^{4}$ Stutthoffi laagrit kirjeldav Sruoga nimetab neid surmakandidaatideks, esitades neist samas pika portree (1976: 98jj). „Musulmani” hüüdnime tekkelugu on ebaselge; mõne tõlgenduse kohaselt tulenes see lõpuni kurnatud vangide küürus olekust, mis meenutas moslemite palvekombeid. Mujal kasutan terminit ilma jutumärkideta, arhailine sõnavorm peaks seda islamiusulistest piisavalt eristama, liiatigi ei tehta moslemitest selles töös juttu.
} 
Tuleb silmas pidada, et musulmanid pole loomastunud olendid, sest neis pole kustunud mitte üksnes tahte aktiivsus, vaid ka instinktid - nad ei suutnud sageli vahet teha külmanäpistusel ja valvurite peksul (Agamben 2009: 198). Loomastumise näitena sobiks mainida hoopis siin-seal laagris puhkenud kannibalismi: näiteks sööstis näljast hullunud vang äsja surnud keha kallale, rebides talt maksa välja (Sruoga 1976: 87). Musulmani elu tundub olevat täielik neeldumine igapäevaste tegevuste automatismi, masinlik kulgemine sunnitööle ilma enese alalhoiuks vajaliku kavaldamiseta, ilma tulevikulootuseta, kuid juba otsapidi teises ilmas, „kus pole mälu ega südamevalu” (Agamben 2009: 198). Kasutasin ebalevat sõnastust tundub olevat sellepärast, et musulmani teadvusest pole võimalik anda esimese isiku kirjeldust, kõik kirjeldused on esitanud kõrvaltvaatajad, kes pole allaandmise piiri ületanud.

Juriidilises plaanis on kõik koonduslaagri vangid muudetud paljaks eluks, õigusteta kehadeks, keda mitte ei karistata ega kasvatata ümber, vaid neist lihtsalt kurnatakse enne hävitamist sunnitööl välja viimane energiaraas. ${ }^{5}$ Kuid faktiliselt viiakse see biopoliitiline taandus lõplikult täide alles musulmani kujus.

Jaan Oksa novellides avaneb seesama paljas elu just talupoja figuuris. Asi pole pelgalt selles, et taludes elatakse poolnäljas ja tehakse kurnavat tööd: „Soo on täis väsinud nägusid - need on ise kõik vikatiga surmad” (Heinamaal”, OM: 75); „Neil tüdrukutel on suured inetud kõhud ja jämedad, päris pakkjalad. [---] Naised ja laste-emad räägivad, et lahja leem on seda teinud, haruldane vesikartul ja katkuv-hapu taar” („Küla”, OM: 366). Olulisim asjaolu, mis tekitab musulmaniga olemusliku sarnasuse, seisneb selles, et Oks a te gelas tel pu udub suunatus tulevikku, õnneihalus. ${ }^{6}$ Ollakse pääsmatult kinni argielu „rõhutud ringides”. Selline argine eneseküllasus iseloomustab ka neid Oksa eespool mainitud tekste, kus pelgalt visandatakse argielupilte, kuid antud kujutamisviisi märkamiseks tuleb pöörduda sääraste novellide poole, kus kirjeldused on intensiivsemalt pessimistlikud ning hinnangulised. Võrrelgem järgmisi katkendeid eeltoodud tsitaatidega musulmani elust.

Imelikud visad on hinge-loomad. Uppunud on juba, uppunud inimene halli töömure, toimetuste, odavate liikumiseavalduste sisse - au on ära pleekinud, häbi algosadeks langenud, kõik on ära kõdunenud... aga hing ei sure. [---]

Äraehtinud vesinägudega, kaeladega, mis ära on väsinud otstarbeta-rumalat ihuosa kandmast - inimesed. Kirgede hangunud jäljed, nälgade südameta-hooletud päka pigistusmärgid... See on nende nägu, see on nende pea, kus ükski haige mõte enne surma terveks ei ole saanud, kus mitte midagi valmida ei ole jõudnud. Suruvad-suured, tönts-paksud klambrid kustutavad liikumise enneaegu, enne valgust, enne soojusejõudu.

Näib, nagu oleksid nad end kogemata-meelega ära unustanud, et mõisates tööjõud ei väheneks, et inimesed uhkeks ei saaks minna, et virinat ja loomalik-tumma rahulolemist oleks tervel elupõrandal, orgudes, mägedel ja soodes.

\footnotetext{
${ }^{5}$ Sruoga põhjalikust eritlusest (1976: 139-164) paistab, et vähemalt mitte kõikides koonduslaagrites ei moodustanud sinna suletud de jure ühtlast massi, eri „tähekeste” kandjate staatused erinesid pisut ning erandjuhul oli võimalik isegi laagrist vabaneda.

${ }^{6}$ Kõige paremini tuleb see eripära ilmsiks, kui võrrelda Oksa ja A. H. Tammsaare tegelasi. Viimasel pole õhk tulevikku suunatud taotlustest ja nende traagilisest luhtumisest tiine mitte ainult „Tões ja õiguses”, sama üldinimlik olukord kannab juba karjapoisi elu novellis „Tähtis päev”.
} 
Nagu kellegi sümbolid, ainult odavad sümptomid millestki lõpmata ollusest. („Vaevademaa”, OM: 150-151)

Ja veel viserdavad väiklased-väiksed inimesed ajas ja ruumis. Vesise, uppuva välja ääres liiguvad näljaste inimeste kehad, poevad vaikivatesse peavarjudesse... jõuetuses ennast ära süües. („Vaevademaa”, OM: 153)

Inimesed elavad ja liiguvad ning nende elu on tuhandatel kordadel tume ja udune kui sügisene päev. Paljud elavad kõik oma elu silmapilgud niisuguste hallide varjude sees, nad on raudades ja ahelates ilma tundmata ja aru saamata, nad usuvad, et nemad ka midagi mõistavad, näevad, aga see igavesti kivistatud eluring surub silmad kinni, matab nende arusaamise paksude katete alla, suleb kõrvad ja litsub lämmatavalt suu peale... („Otsija metsas”, OM: 385)

Mõistagi ei ole mõne katkendi tsiteerimisega võimalik avada kogu Oksa juttude kummastavat miljööd, kuhu kuulub kindlasti ka trööstitu loodus, pidev vihm ja pori jne. ${ }^{7}$ Siiski julgen väita, et esiletoodud katkenditest kumab läbi seesama paljaks eluks nimetatud eluvorm, mis saab hiljem koonduslaagrites musulmani nimetuse: kurnatud, apaatne, vagane kuju, kes ei reflekteeri oma elu üle ega mässa. Ta on hajuva subjektiivsusega „sümptom millestki lõpmata ollusest" - paljast elust, milles puudub inimlikule eluvormile omane mõte.

Oksa loodud küla on omamoodi musulmanide kuningriik, allajääjate maailm. Kõik sotsiaalsed lõhed, võitjate-kaotajate vahelised pinged ja vaen (mõis ja küla, vaesed ja tõusikud - „säärased mulgid”, peremehed ja sauna-Jussid jne) on siin minimaalseks redutseeritud. Oksal on mõni üksik novell („Taida tütar”, „Tume inimeselaps”), mida kannab üksikisiku ja kogukonna konflikt, kusjuures peagi näeme, et see konflikt osutub Oksa autorihääle seisukohalt tõrjutute jaoks omamoodi väljapääsuks.

Ka Oksa puhul jääb kehtima koonduslaagrite kohta öeldu: musulmanide kirjeldamiseks on vajalik kõrvaltpilk, kuid Oksal ei kuulu see mitte mõnele teistsugusele tegelasele, vaid loo kohal kõrguvale autorile. Üksnes selle vaatleja jaoks on paljas elu piinav, alandav kogemus, hämarolekus endas ei tundu olevat $^{8}$ erinevust selle vahel, kuidas o $\mathrm{n}$ ja kuidas p e a $\mathrm{s}$ o l e m a. Nii musulmani kui ka külaelaniku elu saab nimetada vaevaks üksnes ses tähenduses, et neil on, erinevalt näiteks koomas viibivast kehast, säilinud afektiivsel tasandil mõned kurnavad impulsid.

Eelnevalt tsiteeritud Oksa tegelaste kirjeldused on üldist laadi ning sisaldavad spekulatsioone nende teadvuse üldisest olukorrast. Sellele nägemisviisile lisab Oks veelgi „kütet”, põimides oma novellidesse filosoofilis-esseistlikke mõtisklusi palja elu mõtte üle. Asumegi nüüd neid mõttekäike jälgima, püüdes seeläbi jõuda artikli hüpoteesi kinnitamiseni.

\footnotetext{
${ }^{7}$ Selle kirjatöö maht ei võimalda võrrelda Oksa novellide maastikke koonduslaagri topoloogiaga; need mõlemad on trööstitusse porri uppuvad ruumid, nii et võrdlusalust jaguks.

${ }^{8}$ Seda saab oletada välise vaatluse põhjal. Mõistagi võib alati spekuleerida, et kannatus on nii seesmine, et ta lihtsalt ei väljendu.
} 


\section{Palja elu teoreetiline kontuur Oksa üldistustes ja hinnangutes}

Korrakem üle, et musulmanid ise lugusid ei jutusta (Agamben 1999: 33), vaja on kõrvalist häält. Kui laagrilugusid räägivad ellujääjatest õnneseened, siis Oksa novellides vaatleb külaelu enamasti imaginaarne autorihääl, kes ei piirdu pelgalt olukorra mustades toonides kirjeldamisega, vaid annab endast lisaks märku üldistuste ja hinnangute abil. ${ }^{9}$ Jutustavate häälte erinevus pole pelgalt positsiooniline - ühel puhul sündmustes viibiv tegelane, teisel puhul sündmuste kohal kõrguv vaatleja. Suur erinevus paistab silma just järelduste laadis ja üldistuste määras. Laagrilugudes käsitletakse olukorda, kus mitte üksnes ei hävitata massiliselt ja süsteemselt inimolendeid, vaid „toodetakse” inimestest tundetuid musulmane, karjuva ebaõiglusena, ilmselge eriolukorrana, mille pelgast kirjeldamisest piisab moraalse hinnanguni jõudmiseks. Kui mõni autor ka spekuleerib, et laagris avaldub kõikjal elus esinev olelusvõitlus ning jagunemine ellujääjateks/allajääjateks (Levi 2004: 75-76), siis rõhutatakse ometi, et inimese viimine n-ö olelusvõitluse nulltasandile on üüratult ebaõiglane. Oksa juttudel on hoopis teine „moraal”: tema lugude jutustaja asub samuti mannetust vaevaelust kõrgemal ning suudab selgelt näha sellise elu ebainimlikkust, vääritust. Kuid erinevalt laagrielust jutustajatest puudub sellel vaatlejal-hindajal igasugune tulevikulootus ning samuti lootus, et vaevaelust võiks kujuneda sügavamalt mõttekas, isiksust arendav kannatus (vrd Frankl 2002: 94). Oksa autorihääl on läbinisti pessimistlik-dekadentlik: külaelu pole tema jaoks mitte elu madalaim äärmus, vaid elu kui sellise mudel palja eluna. Kõige selgemalt ja intensiivsemalt on säärased üldistused avatud novellis „Neljapäev”, kus need eelnevad sündmuste kirjeldusele, kuid sama mõtteliini leidub ka teistes tekstides.

Sa suur ja saladuslik Kõik: piirideta vabade-vaba ainukene olemasolemine vältus! Ja muud ei ole ju: sest ka inimene on vältuse tühine omadus...

Igapäevane närune neljapäev - külmade, eluta huvidega. Ei ole ju - kellele muud, kõrgemat, tarvis läheks. Ei ole ju! Kordub ja kordub... vana laul. Kuus päeva - ja jälle... kui tihti ja toreduseta! Kuus päeva: ja jälle... („Neljapäev”, OM: 135)

Tulevikus ei ole midagi, sellepärast et ka tulevikku kellelgi ei ole. On ainult piirita-rumal olevik. („Neljapäev”, OM: 136)

Mõõduta rumal ja armetu alatu on see elumõte - inimese elu alalhoidmise mõte. Nurjatus, kurat! Sa elad - ja ise ei tea, mispärast! Sa ei tea? Narrikene - niisugune! („Suu”, OM: 201)

Kõik on elus väga lihtne ja arusaadav, nagu elu ise väga labane ja ühepoolne on. Sa sööd, et tööks rammu saada, ja teed tööd, et rammu ära kaotada, et jälle süüa ja jälle tööd teha. Ja töö on nagu ajaviide söögikordade vaheajal. Terve elu pole muud kui mööda libedat katlapõhja ronimine, kus kõrbenud pudrutükid peale jäänud on. („Taida tütar”, OM: 373)

\footnotetext{
${ }^{9}$ Mööndavasti on eelnevalt tsiteeritud tekstidest nüansseeritum näiteks Oksa lühike novell „Isa ja pojad”, mis kirjeldab kolme metsatöölise - isa ja kahe poja - rasket ja lootusetut tööelu. Sealsete tegelaste sisemonoloog annab selget tunnistust inimlikust eluvormist.
} 
Juba nendes nappides katkendites sisalduvad kõik palja elu kontseptsiooni olulisemad tunnused: vältus kui mõttetu pelgalt elusolemise fakt ning tuleviku (st tulevikuootuste) puudumine. Tsiteeritud kirjakohtades jagatakse elule sääraseid hinnanguid n-ö linnulennult, kuid mõnikord kasvavad sarnased üldistused välja ka mõne tegelase lähivaatlusest:

See on ju vana isa loomusunni eksitus, kus ta teadmata-tahtmata edasi peab elama... igavesti, kui veel ei pea lõppema see räbal vaevaelu, - igav, tühine mõistatus. („Isa ja pojad”, OM: 109)

Kaks perekonda: isa ja poeg oma naisega. Mõlemad on armastanud, elanud ja lootnud, kõik kaotanud ja kõik jälle leidnud. Nüüd läheb elu igapäevaselt, tüütavalt, hoopis lõbusalt - nagu unes, nagu ilmsi. Mis elu see õieti on; on see mõistatus või ainult perioodiline söömine, see ei huvita enam. Elatakse ainult - sellest on küll. („Perekonna hommikutund”, OM: 130)

See ongi Oksa proosaloomingu elufilosoofia: palja vältuse olukorrast pole võimalik edeneda ja seega ei ole elu elamist väärt. ${ }^{10}$ Üliharva leiame Oksa proosast abstraktset õhkamist parema elu järele: „Kui veel midagi oleks peale pori vormita tänaval, kui veel midagi oleks peale lootuseta närude ja sõnnikuleiva. Kui veel midagi oleks!” („Vaevademaa”, OM: 149); „Nagu korraks, nagu korraks venib lollide ringi roomav-odav unistus. [---] Kivid kõduneksid sõnnikuks - kõigil oleks ruumi - natukene maad - lastel oleksid saapad - lehm kõnniks õues - ja isa ostaks vilja... / Nagu oleks nii olevat - ja kui see nii oleks” („Vaevademaa”, OM: 153). Aga midagi muud ei ole ega tule, seetõttu on paljas elu surmast hullem:

Orjade küla - vaesusega halvatud, nii varatu jõududes, nii võimetu vähemakski loomiseks. See on ju midagi suurt halba, kui midagi surra ega sündida pole, kui asjad isegi allpool hävitamist, püha hävitamist seisavad, et ka enam lõhkumises mõtet ei leia, ja nii sellestki tundmusest ilma pead olema, mida loomise igatsus südames äratab. See on ju midagi näotumat kui lihtne haledus, nii et ka enam kaastundmus külge ei hakka. („Küla”, OM: 363)

See järeldus kandub Oksa loomingus sirgjooneliseks normatiivseks programmiks: igaüks, kes suudab palja elu tardumusest kõrgemale tõusta ja elu kriitiliselt küsitleda, peab jõudma järeldusele - tuleb surra! See tõdemus avaldub nii sündmuste sekka poetatud autori hääle sosinatena („Kao udusse ja sure...” („Otsija metsas”, OM: 390)) kui ka tegelastele suhu pandud pikemate manifestidena („Vana madrus”, „Hauakõne”). „Hauakõnes” jõuab see mõttekäik äärmusse, üldise teesini sündimise ebaõnnest:

Sündimisega on inimese elu mõtteline tähtsus ära kägistatud, igasugune elu sisemine mõte maha maetud. Järele on jäänud peale sündimist midagi ilmaasjatut, mida igaüks ära kaotada tohib. Alalhoidmiseks ei leita igaveses ajavältuses ühtegi põhjust peale rumaluste. (OM: 160)

${ }^{10}$ Oleks viga järeldada, et see on Jaan Oksa kui inimese lõplik elufilosoofia. Oksa eluolulistes ajaleheartiklites (Oks 2004) on jälgitav argise elujärje parandamise taotlus, samuti leidus tema eraelus väidetavalt parasjagu revolutsioonilist mässumeelt. 
Seda äratundmist võib hilisemat moesõna kasutades nimetada eksistentsiaalseks heidetuseks, aga ilma mingi Sisyphose naeratuseta. Konkreetsemalt häirib eksistentsiaalset mõttetust kogevat subjekti just palja elu vältuse nüridus ümbritsevates inimestes. Selle nüristava passiivsuse vastu leiabki Oks rohtu surma sööstmise heroilises aktiivsuses:

Pühitse elamisehullumeelsust... hävita see tugev ilmaelu lolluste kogu - elamisetung ja tahtmine eneses ära, nii rändad ennem eesmärgile, langed lollustesse.... Aatomina on magus: pole vihata ega vihatud saada - pole vaja igavatesse nägudesse vahtida... („Suu”, OM: 202; vt ka „Udukogus”, OM: 200)

Ma austan otsustava jõu võimu! [---]

Elu on teotav, elu on tülikas, vastik, häbi! Surm on tõde, surm on elu eesmärk. Uhkelt on surra vaja. Muid põhjusi, järeldusi, eesmärke ei ole. Kõik on lihtne umblollus... („Hauakõne”, OM: 160)

On huvitav märkida, et see raev jääb Oksa tekstides deklaratiivseks ega kandu sündmustiku tasandile. Ühtegi amokijooksu seal ei leidu, kõige vägivaldsemaks teoks jääb lapsetapp novellis „Taida tütar”. Elu hülgamise tehniliseks viisiks pole Oksa proosas mitte mõni kiirlahendus, vaid vaikne metsas kõngemine. Kõige reljeefsemalt on seda protsessi kirjeldatud novellis „Tume inimeselaps”. Külakogukonnas alavääristatud poiss põgeneb korduvalt metsa ning kogeb seal hääbumise ahvatlust:

Abita lehtede mädanemine. Poisike ootab ja tahab nii kaua uhkelt vaikida, kuni ka tema ükskord nende surevatega ja surnutega siin tihedas rapikus kopitab ja lõhnab, et siis luituda halliks, kergeks ja läbipaistvaks kui kevadine leht. („Tume inimeselaps”, OM: 187)

Loo lõpus lapse soov täitub, põgenemine õnnestub. Algul tuleb joosta, et otsijate eest pääseda ning samuti „elupump ära väsitada” (OM: 192). Järgnevalt kirjeldatakse surnuks nälgimise kogemust metsa „võõral-võõral asemel”: „Ei ole midagi. Kõik läheb mööda. Kõik tundmata pigistused kehas, hõõgumine kurgus, rahutus igas soones" (OM: 192). Kui see on möödas, pleegivad lapse luud päikese käes, „[n]atukehaaval ja tasakesi” (OM: 194).

Mida on sellise põgenemisega saavutatud? Paistab, et suurt mitte midagi. Tasakesi hääbudes hajub inimese subjektiivsus samamoodi nagu talupoja töövaeva-elus või koonduslaagri musulmanil. Tuleb rõhutada, et sedavõrd kui kõrvaltvaataja otsustada suudab, ei kannata musulmanid elu käes, on kannatuse kogemiseks liiga nüristunud. Samuti on triviaalne fakt, et vaevaelu ei kesta igavesti, ükskord me sureme niikuinii. Ainus mõistlik tõlgendus tundub seisnevat selles, et Oksa novellides ei suuda erksa vaimuga inimene kogukondlikult hääbuda, vajab põhja minemiseks privaatruumi. Privaatsuse puudumist on probleemina rõhutanud ka koonduslaagris olijad (Frankl 2002: 73-74). 


\section{Paljas elu hea elu ideaalina}

Oksa loomingu maailm on kahtlemata ebaõdus: töövaevas rähklevad talupojad-musulmanid käibivad siin kogu elu iseloomustava mudelina ning ainsa väljapääsuna nähakse hüljata poolsurnute kogukond ning kärvata üksi. Kui tabav on säärane kunstiline elunägemus? Kas poleks meil viimane aeg leida ähvardava palja elu vastu rohtu - kas või Agambeni abil, kelle palja elu käsitus on kriitiline ja pretendeerib emantsipatsioonile? Ehk tuleks liikuda filosoofia valda ning otsesõnu küsida, $\mathrm{m}$ is on h ea elu, kartmata selle küsimuse läbinämmutatud banaalsust? Kas või retooriliselt veenev vastus annaks võimaluse säilitada õnneihalus ning seega inimlik eluvorm. Seda vormi hoiaks juba igavene küsimuse juures püsimine - näiteks sokraatiline hoiak. Neid küsimusi pelgamata pean nentima, et sellise kaaluga probleemide lahkamiseks pole artiklisaba sobiv vorm. Ometi tahaksin küsida, mida saab Oksa looming öelda elu kohta laiemalt. Seejuures tahan vaagida küsimust, mida tähendab Agambeni imelik üldistus, mille kohaselt ähvardab paljas elu täita kogu meie (poliitilist) elu; et laager on maakera uus biopoliitiline nomos (Agamben 2015: 109). Neid küsimusi vaagides pöördun järgnevalt tagasi koonduslaagri vaatluse poole, uskudes seal avaneva pildi valguses, et ka Oksa visiooni võib käsitleda omamoodi prognostilise elu ette käiva peeglina.

Eelnevalt kirjeldasin Frankli mõttekäike tulevikuvisiooni tähtsusest inimelus: „Kui elu mõte sõltub sellest, kas jäädakse ellu või mitte, kui elu mõte sõltub juhuse tahtest, siis pole elu elamist väärt" (Frankl 2002: 94). Ka laagris esines kõigi loetud autorite väitel enesetappe, hüpati elektrivooluga traatidesse (Frankl 2002: 32) või poodi ennast üles (Kaugver 1989: 7). Inimeseks jäämise manifestina armastatakse rõhutada juhtumeid, kus keegi ohverdas vabatahtlikult oma elu teiste nimel (vt Pojman 2002: 262); ennekõike jätkus sellist meelekindlust religioossetel inimestel. Raimond Kaugver (1989: 69-71) kirjeldab Solonka saarte vangilaagris levinud „moodi”, kus vangid raiusid metsatöödel maha oma jäsemeid, heites neid palgikoormate sekka ning kirjutades palkidele verega oma lugu, sageli seejärel verest tühjaks joostes. Just vajadus laagrikogemusest maailmale rääkida, olla tunnistajaks, toimis paljudel juhtudel elu mõtestava eesmärgina, mis ei lasknud inimestel alla anda. Frankl (2002: 93) üritas isegi tõlgendada laagrikatsumust Dostojevski vaimus isiksust arendava kannatusena, mis kutsub inimest olema oma piina vääriline. Viimaks tuleb mainida ka võimalust valida põgenemine. Kõikides laagrimälestustes rõhutatakse asjaolu, et õnnestunud põgenemisi tuli ette üliharva; sestap ei olnud põgenemine eriti moes isegi sõja lõpul, mil valve nõrgenes. Kõik eelnevalt toodud näited (enesetapp, eneseohverdus, kannatuse teadlik läbielamine, põgenemine) kirjeldavad aktiivseks autonoomseks subjektiks jäämist ekstreemsetes tingimustes. Tasub tähele panna, et selline eluhoiak ilmestab harvaesinevaid ja hävinevaid äärmusi. Nii nagu musulmanid, kadusid ka pühakud gaasikambrisse ning põgenejad püüti enamasti kinni ning hukati avalikult.

Vaadelgem nüüd, lähtudes siinses artiklis kasutatud kirjelduste piiratud hulgast, kuidas kulges laagris ühe keskmise ellujääja elu. Oleme seda teemat musulmani analüüsi puhul juba põgusalt valgustanud: laagrielu argipäev on pidev võitlus ellujäämise eest. Kuna mälestusi kirjutasid just ellujäänud, on meil tolle igapäevase katsumuse kohta võimalik lugeda hulganisti detailseid kirjeldusi. 
Musulmanid hoiatava näitena silme ees, pidi vang igal hetkel aduma, et tema elus püsimine nõuab pidevat kalkuleerimist ja kombineerimist. Kui saatus oli talle kätte mänginud privilegeeritud ametikoha, tuli sellest kinni hoida, hoiduda ülemuste soosingut hävitavatest vigadest - sest ükski positsioon polnud muutumatu (vt Sruoga 1976). Kui töötati harilikus komandos, tuli püüda ennast sättida sellise töö peale, kus oleks võimalik kõige rohkem „viilida”. Kui eluspüsimiseks vajalikku lisapajukit hangiti mingi osava tehingu kaudu väljastpoolt laagrit, tuli pidevalt vahelejäämist vältida (vt Frister 2002: 33-34) jne. Kuigi eri autorite jutustustes mängivad õnnelik juhus ja isiklik aktiivsus toimetuleku puhul erinevat rolli, on pidev askeldamine vältimatu - magavale kassile hiir suhu ei jookse.

Natsilaagritest pajatavates raamatutes ei paista see pideva askeldamise visadus iga kord silma, kuna tähelepanu fookusse kerkivad koletumad sündmused, nagu selektsioonid hukkamiseks ning kapode vägivald reavangide kallal. Lisaks kruvib nendes teostes pinget sõja lõpuga saabuv suurte segaduste periood laagris. Parimaks ellujääja argipäeva kirjelduseks tuleb minu hinnangul pidada hoopiski Aleksandr Solženitsõni (1963) jutustust „Üks päev Ivan Denissovitši elus". Raamat kirjeldab staažika vangi Šuhhovi toimetustest tulvil päeva stalinistlikus Nõukogude vangilaagris. Olgugi et gaasikambri ähvardus puudub, tuleb ka seal eluspüsimiseks pidevalt normipajukile lisa hankida. Suhhov pole õnnesärgis sündinud, vaid peab lootma üksnes iseenda usinusele ja kavalusele, ta ei tööta „sooja koha” peal ning erinevalt paljudest kaasvangidest ei saa ka kodust pakke (Solženitsõn 1963: 87). Šuhhovi toimetulekustrateegia seisneb mõjukamatele ja jõukamatele vangidele pidevate teenete osutamises: küll seisab ta kellegi eest pakijärjekorras, küll peidab oma madratsis keelatud nuga, mida teised vorsti lõikamiseks laenavad jne. Kõiki sääraseid teeneid osutab loo peategelane targalt-delikaatselt, mitte pealetükkivalt ega ka manguvalt. Sellest tulenevalt saabki Šuhhovi vaev laagris kehtiva teenete ökonoomia alusel tasutud, näiteks loovutab jõukas pakisaaja talle sabas seismise tasuks oma normiportsu. Säärane osavus pole sugugi igaühele omane, jutustuses on kujutatud ka Šuhhovi vastandit, saamatut Fetjukovi, kes käib suure näljaga sööklas toidujäänustega kausse lakkumas ning saab selle eest pidevalt peksa. Kausilakkujad on stalinistlikus laagris musulmanide analoogiks, neile pole ette nähtud ellu jääda. „Kui nii võtta, siis on temast kahju. Oma vangiaega ta lõpuni ei ela. Ei oska meeste hulgas mees olla," mõtleb Šuhhov (Solženitsõn 1963: 102).

Kuigi nõukogude vangidel on alles teatav poliitiline subjektsus, neid ei tapeta valimatult ning isegi nende vangistus on tähtajaline, muutuvad kõik kaugemad eesmärgid ja plaanid Šuhhovi mõtetes ebamäärasteks ja hägusateks. Võiks isegi ettevaatlikult oletada, et ta on laagris kodunenud. Tema tegus päev lõppeb järgmise kokkuvõttega:

Šuhhov uinus ja oli täiesti rahul. Tänasel päeval oli tal paljugi õnneks läinud: kartsa ei pandud, brigaadi sotslinna ei aetud, lõunaks sai pudruportsu pihta panna, brigadir tingis välja hea protsendi, seinaladumine läks Šuhhovil ladusasti, puistamisel ei jäänud saelehega vahele, õhtul teenis Tsezari käest leivalisa ja ostis tubakat. Ja ei jäänud haigeks, sai tõvest võitu.

Oli möödas päev, mida miski ei tumestanud, peaaegu et õnnelik päev. (Solženitsõn 1963: 113) 
Sarnases rütmis toimetavad kõik laagrijuttude minategelased: nad on ellujääjad, kelle meeled on alati erksad, haaramaks kinni igast lisapajuki organiseerimise võimalusest. Kindlasti on siin tegemist eluvormiga: need inimesed on suunatud tulevikku ning on kantud õnneihalusest. Aga see õnneihalus ei hõlju elu mõtte üle peetavate abstraktsete vestluste elevandiluutornis ega avaldu kentsakates irratsionaalsetes tungides, vaid paljas elamise faktis e nd a s - see, kes on ka homme elus, võibki ennast õnnelikuks pidada.

Siit koorub välja mõnevõrra üllatav järeldus: paljas elu pole mitte üksnes õõvastav fakt, musulmani vormis avalduv äärmus, kus inimlik õnneihalus on teadvusest välja voolanud; paljas elu pole kaugeltki mitte üksnes laagrielaniku pelgaks numbriks taandatud juriidiline identiteet. Paljas elu on palju enamat: see on valdava enamiku tegusate laagrielanike käitumist organiseeriv ülim väärtu s. Frankli (2002: 50) sõnutsi: „Laagrivangide valdavat enamikku juhib primitiivne tung keskenduda lakkamatult ohustatud elu alalhoiule, kõige selle radikaalse väärtusetuks tunnistamisele, mis ei teeni elu säilitamise erieesmärki." Laagris on eriolukord muutunud normiks (Agamben 2009: 182) ning ellujäämise nimel on vangid selle normatiivse paradigma omandanud. Just säärase väärtushoiaku juurutamises seisneb paljast elu tootva poliitika ülim võit, selle võimurežiimi produktiivsus. Käesoleva artikli viimases osas üritan näidata, et antud surve ja ähvardus ei iseloomusta üksnes ekstreemolukorda laagris, vaid laiemalt meie igapäevast tegelikkust.

\section{Lõppjäreldused}

Selles artiklis kaitsesin hüpoteesi, et Jaan Oksa proosaloomingu muudab kummastavaks just paljas elu, nüri kestvus ilma inimesele omase õnnetaotluseta. Äärmuslikes vormides võtavad Oksa kujutatud talupojad poolteadvuseta „elavate surnute" kuju, milles leidub märgatav sarnasus koonduslaagri musulmanidega. Kuid ka nendes juttudes, kus külaelu ei kujutata nõnda tontlikult, jääb valdavaks miljööks argine tuimus, igapäevaelu elamine ilma kõrgemate sihtideta ja suuremate unistusteta. Säärane eluhoiak, kus elu ise on ülim väärtus, mille nimel tuleb usinasti toimetada, käibis ka koonduslaagris nn ellujääjate seas. Oksa loomingut pingestab paljast elust distantseeruv vaatleja, hääl, mis käsitleb kirjeldatud külaelu elu kui sellise üldise mudelina, kuulutab säärase eksistentsi mõttetuks ning propageerib muud lahendust leidmata väljapääsuna vabasurma. Oksa loomingu põhiline saavutus seisneb minu hinnangul palja elu täpses kujutamislaadis, selles lunaatilises ja laialivalguvas ebaluses, mis jääb püsima muuhulgas seetõttu, et ei võta ühegi ühiskondliku vastasseisu kuju. Sedasama eelist poliitiliselt angažeeritud kirjanduse ees kannavad maailmakirjanduses näiteks Kafka ja Becketti teosed.

Kas teostatud võrdlusel võiks olla ka mingi laiem, kirjandusest välja ulatuv „moraal”? Kuigi Oksa looming ei pretendeeri elu kopeerimisele, pole see ka täielik ulme; siin on paras annus naturalismi (vrd Lust 2015). Võiks spekuleerida, kas tema kunstilises visioonis ei vilksata mõni oluline kaader Eesti külaelu kohta. Seda elu läbistav sajanditepikkune nälg ja töövaev võivad olla Oksa novellides kunstiliselt võimendatud, kuid mitte välja mõeldud. Kui asetada korraks Oksa kunstnikupilgu kõrvale Karl-Ernst von Baeri teadlasepilk, paistavad meie esiisad ka sellest perspektiivist märgatavalt musulmaniga sarnased: 
Madal vaimne kultuur on põhjuseks, miks eestlased peaaegu ei suuda oma seisundit täpselt kirjeldada. Oma flegmaatilise is eloomu ja sügava ükskõiksuse tõttu, mis väga paljude haiguste puhul tunduvalt suureneb, nad mitte üksnes ei jälgi iseennast, vaid sageli ei vaevu oma hädast arstile täpsemalt rääkima, veel enam seetõttu, et nad arstiteadust vähe usaldavad ja is egi surmast ei hooli. (Baer 1976: 43; minu sõrendused - L. L.)

Mõelgem Oksa loomingu ja koonduslaagrikirjelduste valguses järgnevatest märksõnadest, mille abil tavatsetakse spekuleerida eestluse tuuma üle: jonn, visadus, töökus, paigal püsimine, talupojatarkus. Seda komplekti ülistatakse omamoodi immanentse filosoofiana, tarmukamad tõlgendajad kõnelevad koguni eesti eksistentsialismist (Rein Veidemann) või eestlaste elu kandvast animismist (Valdur Mikita). Ehk on sellise eluhoiaku tabavam nimetus hoopiski paljas elu? Mõelgem kas või Kaido Kama (2013) katsele väärtustada pärimuskultuuri just ellujäämisstrateegiana: talupoja oskused, tavandid ja uskumused teenivad seal ennekõike ellujäämise eesmärki ning meie tänases urbaniseerunud-läänestunud kultuuris säärased oskused puuduvad. Kama jutt on ülimalt õige - juhul kui on õige elu e n d a säilitamine ülima eesmärgina -, kuid kas ei taha me sääraste väärtushinnangute kaudu põlistada maailma koonduslaagrilaadse paigana, kus kogu energia ja õppimisvõime tuleb suunata lisaportsu organiseerimisele?

Kahtlemata tuleb Oksa kunstilist elu mudelit isegi Eesti elu kujutamisel hinnata kitsaks ja ühekülgseks. Nagu mainisin eelnevalt musulmani alateemat analüüsides, kujutab Oks isoleeritult allajääjate maailma. Nii eesti kirjandusest kui ka ajalookirjutusest leiame palju aktiivsust, pihtahakkamist ja ka taotluste luhtumisega seonduvat traagikat. Talude päriseksostmine, uudismaa raadamine, parema elu nimel „keisri usku” minemine ja väljarändamine, Mahtra sõda, mõisate põletamine jne - eesti kirjanduse tuumtekstid koosnevad paljuski just loetletud katsumustest, millele lisanduvad pidevad argised hõorumised erineva sotsiaalse staatusega inimeste vahel nii maal kui linnas. Siinkohal tasub viivuks meenutada Mihkel Muti põnevat loominguökonoomilist mõtisklust eesti kultuuritegelaste päritolu kohta. Elulugusid lapates paneb Mutt tähele, et mõne üksiku erandiga ei võrsunud Eesti vaimuelu mitte Oksa kirjeldatud näljaelust ja sopasest hütist, vaid end juba paremale järjele sättinud nn vahekihist, kelle seas olid tähtsal kohal ka mõisateenistujad: kupjad-kiltrid-aidamehed (Mutt 2014: 85-87). Viimaste suhteline jõukus tulenes paljuski ka suguvendade sundimisest. Mutt visandab oma artiklis paralleeli hilisema kommunistliku partei liikmeskonnaga (2014: 88 jj), siinse artikli raamistikus võib neid võrrelda laagri kapode ja blokivanematega.

Üritagem tõlgendada Agambeni väiteid, mille kohaselt „Lääne biopoliitiline paradigma on tänapäeval koonduslaager, mitte polis" (Agamben 2009: 194) ning paljas elu on muutunud igal pool dominantseks eluvormiks (Agamben 2015: 85). Nende väidete ammendav kaalumine nõuaks Agambeni mõttekäikude pikemat eritlemist; kindlasti on tema Foucault' jälgedes käivate uurimuste põhifookuses biopoliitika ehk mehhanismid, kuidas võim avaldab üha enam mõju meie kehadele (vt Agamben 2009: 134 jj). Siinkohal peatun põgusalt üksnes elu mõtestamise teemal. Kui rääkida poliitika makrotasandist, siis ühendab paljusid kontinentaalseid mõtlejaid murelik tähelepanek, et poliitika on käinud alla ja muutunud halduseks: ei toimu olemuslikku konkurentsi eri- 
nevate hea elu visandite vahel, vaid üksnes elatusvahendite rehkendamine (vt Monticelli 2016). Kui Aristotelese jaoks kuulus elu enda säilitamine, sh majandamine, privaatsfääri (oikos'esse, vt Lipping 2004), siis moodsas lääne mõtteruumis on maailm ökonomiseerunud, muutunud majandusmaailmaks, milles poliitika põhiülesandeks on inimelude säilitamine, palja elu säilitamine (Agamben 2009: 16). Koonduslaager on sellise poliitilise situatsiooni ehedaim mudel, koht, kus linn (polis) ja kodu (oikos) on muutunud eristamatuks (Agamben 2009: 201).

Säärasele tegelikkusele on väga raske vastu vaielda, sest ükskõik millise muu eesmärgi täitmiseks on ju esmalt vaja elus püsida. Huvitaval kombel ei ole teaduslik-tehniline progress meid palja elu küüsist vabastanud: esiteks on meil üha rohkem teadmisi maailma globaalse situatsiooni ökoloogilis-energeetilisest haprusest; ${ }^{11}$ teiseks tundub majandusüksuseks taandatud maailmas hoogustuvat uus rahvaste rändamine rasvasema supikatla juurde (mitmete analüütikute arvates peitub see tõmme ka praeguses Euroopa pagulaskriisis). Meenutame Agambeni ütlust, et õnne hoolde antud olendina on inimese elu kohe ka poliitiline elu. Paljas elu avaldab survet igale üksikule inimesele: see nõuab, et inimene võtaks sisse askeldaja positsiooni liberaal-majanduslikus „laagris”, kuulutaks ellujäämise ülimaks eesmärgiks. See on inimelu läbistav totaalne mobiliseering, mida nimetatakse loosungite keeles meelitavalt näiteks elukestvaks õppeks, just nagu Auschwitzi värava kohal kõrgub tänini silt „Arbeit macht frei”. Ka musulmanid on tänagi distsiplineeriva hoiatusena kohal, vaaruvad jalgu järele vedades prügikastide vahel, ning nagu laagriski, on ellujääjad õppinud neist mööda vaatama. ${ }^{12}$ Visandatud võrdlust tuleb muidugi võtta võrdpildina, otseses mõttes nälga surrakse vähemalt esimeses maailmas harva ning kombineerimine käib enamasti (veel) esmasest kõhutäiest „kõrgematel” tasanditel. ${ }^{13}$ Aga need erinevused ei muuda põhilist tõika, palja elu troonimist väärtushierarhia tipus, äraelamise muutumist õnneliku elu ideaaliks. Guy Debordi sõnutsi „äraelamine ise kuulub ilmaoleku valda - ta võib vaesuse üle kullata, kuid ei suuda seda ületada" (Debord 2013: 34; vt ka Lipping 2004: 194-195). Naljatlevas toonis võtavad moodsa elu kreedo kokku kolm päevavarast filmis „Kaukaasia vang”: elada on hea, aga hästi elada veel parem.

Kuidas antud olukorda suhtuda? Üht võimalikku tõlgendust pakuvad bioloogid-füüsikud; selle kohaselt taandubki kõik üldisele ökonoomiale, palja elu džaulides välja arvutatavatele seaduspäradele ning kõik õhkamised elu kõrgema mõtte järele tulenevad teatavast ajutisest energia ülejäägist (nt filosoofiat võimaldav orjatöö Vana-Kreekas või nafta põletamine tänapäeval). Seda vaateviisi utreerides tuleks öelda, et loodus ise on koonduslaager ja targem on sellega leppida. Mõistagi on olemas ka teisi suhtumisviise, kas või näiteks

\footnotetext{
${ }^{11}$ Eesti keeles vt nt Kaupo Vipi ja Mihkel Kunnuse kirjutisi.

${ }^{12}$ Poeedi ülesandeks kirjeldatud olukorras pole mitte üksnes püsimine palja elu ähvarduse poolt kujundatud meelestuses, vaid kitsamalt selle detailne kirjeldamine, millest üldsus hirmunult kõrvale vaatab, et eluisu pealt ei läheks. Ka poeedi pilk, mitte üksnes filosoofi pilk leiab nähtud äärmustes vihjeid meie üldise saatuse kohta: „Tean, et kui mulle on määratud kogeda äärmust, siis pole sellest mingit abi, kui peidan end parematesse riietesse" (Rilke 1989: 107).

${ }^{13}$ Globaliseerunud maailmas tähendab palja elu nimel rähklemine mõistagi kogu aeg ka seda, et kusagil mujal, teises „tsoonis” surrakse päriselt nälga, sest pajuk on siia „organiseeritud”. Mõned mõtlejad, nt Levinas ja Derrida, on sellele ka tähelepanu pööranud.
} 
erinevad emantsipatoorsed poliitikafilosoofia voolud (vt Monticelli 2016). Ent ka jaanoksalik vaateviis, kunstniku vaateviis pole õnneks kuhugi kadunud. Ka täna leidub kunstnikke, kes kuulutavad palja elu nähtamatut ohtu ja muudavad selle karjuvaks küsimuseks - kel silmad on, see nähku! Eestis on seda ülesannet viimasel ajal kõige järjekindlamat täitnud (:)kivisildnik, kuid kogu kaasaegne kunst on sellest painest tulvil. Meie aja kangelasel tundub olevat valida kahe moto vahel, kas „(lõuad pidada ja) edasi teenida” või:

Miks ma praegusel ajal peaksin elama?

Mistarvis? („Udukogus”, OM: 200)

Autor tänab täpsustavate-kriitiliste märkuste eest Jüri Lippingut ja anonüümset retsensenti.

\section{Kirjandus}

Ag a m be n, Giorgio 1999. Remnants of Auschwitz. The Witness and the Archive. Tlk Daniel Heller-Roazen. New York: Zone Books.

Ag a m b e n, Giorgio 2009. Homo sacer. Suveräänne võim ja paljas elu. Tlk Maarja Kangro. Tallinn: Eesti Keele Sihtasutus.

A g a m b e n, Giorgio 2015. Tulevane kogukond. Vahendid ilma eesmärkideta. Tlk Maarja Kangro. Tallinn: Eesti Keele Sihtasutus.

B a e r, Karl-Ernst von 1976. Eestlaste endeemilistest haigustest. Tallinn: Perioodika.

De B o ever, Arne 2011. Bare Life. - The Agamben Dictionary. Toim Alex Murray, Jessica White. Edinburgh: Edinburgh University Press, lk 30-31.

Debord, Guy 2013. Vaatemänguühiskond. Tlk Anti Saar. Tallinn: Tallinna Ülikooli Kirjastus.

Frankl, Viktor E. 2002. ...ja siiski tahta elada. Psühholoog kogeb omal nahal koonduslaagrit. Tlk Piret Metspalu. Tartu: Johannes Esto Ühing.

Fri ste r, Roman 2005. Müts. Tlk Kristiina Kivil. Tallinn: Vagabund.

Grünthal, Ivar 2001 [1956]. Jaan Oks - alateadvuse anatoom. - I. Grünthal, Müütide maagia. (Eesti mõttelugu 40.) Tartu: Ilmamaa, lk 9-25.

He e r o, Aigi 2005. Jaan Oksa ekspressionism. - Keel ja Kirjandus, nr 3, lk 195208.

Hei d e g g e r, Martin 1967. Sein und Zeit. Tübingen: Niemeyer.

H e i d e g g e r, Martin 1989. Küsimus tehnika järele. Tlk Ülo Matjus. - Akadeemia, nr 6, lk 1195-1222.

Heidegger, Martin 2003. Aja mõiste. Tlk Eduard Parhomenko. - Akadeemia, nr 5, lk 1019-1041.

Ka m a, Kaido 2013. Pärimuskultuur kui ellujäämisõpetus. - Akadeemia, nr 12, lk 2115-2122.

Ka u g ver, Raimond 1989. Kirjad laagrist. Tallinn: Eesti Raamat.

Kerté s z, Imre 2004. Saatusetus. Tlk Sander Liivak. Tallinn: Eesti Raamat.

L a cla u, Ernesto 2007. Bare life or social indeterminacy? - Giorgio Agamben, Sovereignity and Life. Toim Matthew Calarco, Steven DeCaroli. Stanford: Stanford University Press, lk 11-22. 
La cla u, Ernesto 2015. Antagonism, poliitika, hegemoonia. Valik esseid. Tartu: EYS Veljesto.

Levi, Primo 2004. Kas see on inimene. Hingetõmbeaeg. Tlk Maarja Kaplinski ja Mailis Põld. Tallinn: Vagabund.

Li i v, Juhan 1956. Teosed. Tallinn: Eesti Riiklik Kirjastus.

Li p ping, Jüri 2004. Palja elu võimalikkusest Maal (fragment). - Püsimatu metaphysicus. Madis Kõiv 75. Koost Jaan Kangilaski, Bruno Mölder, Veiko Palge. Tartu: EYS Veljesto Kirjastus, lk 187-199.

Luka s, Liina 2005. Kirjanduslikust ruumikujutusest Jaan Oksa ja Eduard von Keyserlingi näitel. - Keel ja Kirjandus, nr 5, lk 345-358.

Luks, Leo 2015. Nihilism ja kirjandus. „Ei” kogemine filosoofia ja kirjanduse ühtesulamisel. Tallinn: Tallinna Ülikooli Kirjastus.

Lust, Kersti 2015. Võitlus näljaga. 19. sajandi näljahädad Eesti külas. Tallinn: Rahvusarhiiv.

Monticelli, Daniele 2016. Poliitika tühisus ja tühjusest võrsuv poliitika. Vikerkaar, nr 1-2, lk 137-148.

Mutt, Mihkel 2014. Kultuuritegijate kujunemisest - moraaliloo taustal. M. Mutt, Õhtumaa Eesti I. Tallinn: Fabian, lk 82-95.

O ks, Jaan 2003. Otsija metsas. Tartu: Ilmamaa.

Oks, Jaan 2004. Orjapojad. Tartu: Ilmamaa.

Pa lg i, Daniel 2003 [1927]. Jaan Oksa proosateoste stiil lingvistiliselt. - Jaan Oks, Otsija metsas. Tartu: Ilmamaa, lk 398-429.

Pojm a n, Louis P. 2002. Eetika. Õget ja väära avastamas. Tlk Tiiu Hallap. Tallinn: Eesti Keele Sihtasutus.

Rilke, Rainer Maria 1989. Malte Laurids Brigge ülestähendused. Tlk Tiiu Relve. Loomingu Raamatukogu, nr 32-35. Tallinn: Perioodika.

Solženitsõn, Aleksandr 1963. Üks päev Ivan Denissovitši elus. Tlk Lennart Meri ja E. Sarv. Loomingu Raamatukogu, nr 11-12. Tallinn: Ajalehtede-Ajakirjade Kirjastus.

Sru oga, Balys 1976. Jumalate mets. Tlk Valvi Strikaitienè. Tallinn: Eesti Raamat.

Süvale p, Ele 1996. Modernist Jaan Oks. - Keel ja Kirjandus, nr 12, lk 793-799.

\section{'Bare life' in camp memoirs and in the prose of Jaan Oks}

Keywords: bare life, Giorgio Agamben, prose of Jaan Oks, concentration camp

The article compares the prose oeuvre of Jaan Oks with certain death camp memoirs with a documentary background, based on the concept of 'bare life' borrowed from the philosophy of Giorgio Agamben. The hypothesis is that Jaan Oks's short stories of village life keep consistently outlining the contours of bare life. Bare life means a life emptied from normal human desire for happiness and for a future. The article compares the peasants depicted in Oks's short stories with the camp residents called 'Muselmänner', who had given up fighting for their lives, thus finding themselves halfway between life and death. In Oks's prose peasant life is also a mechanical existence emptied of all meaning and without any chance of developing one. The consequence is that life is not worth living and suicide is the only exit. 
The final part of the article describes, based on camp memoirs, some of the so-called survival strategies and speculates a little on modern life in general. It is observed that in the extreme conditions of the concentration camp all aims normally giving sense to human life were superseded by the necessity of mere survival, that is, bare life came to occupy people's whole consciousness and their system of values. However, such a shift is not confined to concentration camps only; the end of the article attempts to demonstrate how a similar regard of the mere fact of staying alive as the ultimate value is flooding the whole space of modern thinking.

Leo Luks (b. 1976), PhD, Estonian University of Life Sciences, Assistant Professor of Philosophy; Teacher of Philosophy at Herbert Masing School, Tartu, leoluks@hot.ee 